\title{
OPEN
}

\section{Author Correction: EEG Decoding Reveals the Strength and Temporal Dynamics of Goal-Relevant Representations}

Jason Hubbard, Atsushi Kikumoto \& Ulrich Mayr (D)

Correction to: Scientific Reports https://doi.org/10.1038/s41598-019-45333-6, published online 21 June 2019

In Figure 2, the correct panel B is missing and panel $\mathrm{C}$ is incorrectly given as panel B. The correct Figure 2 appears below as Figure 1.
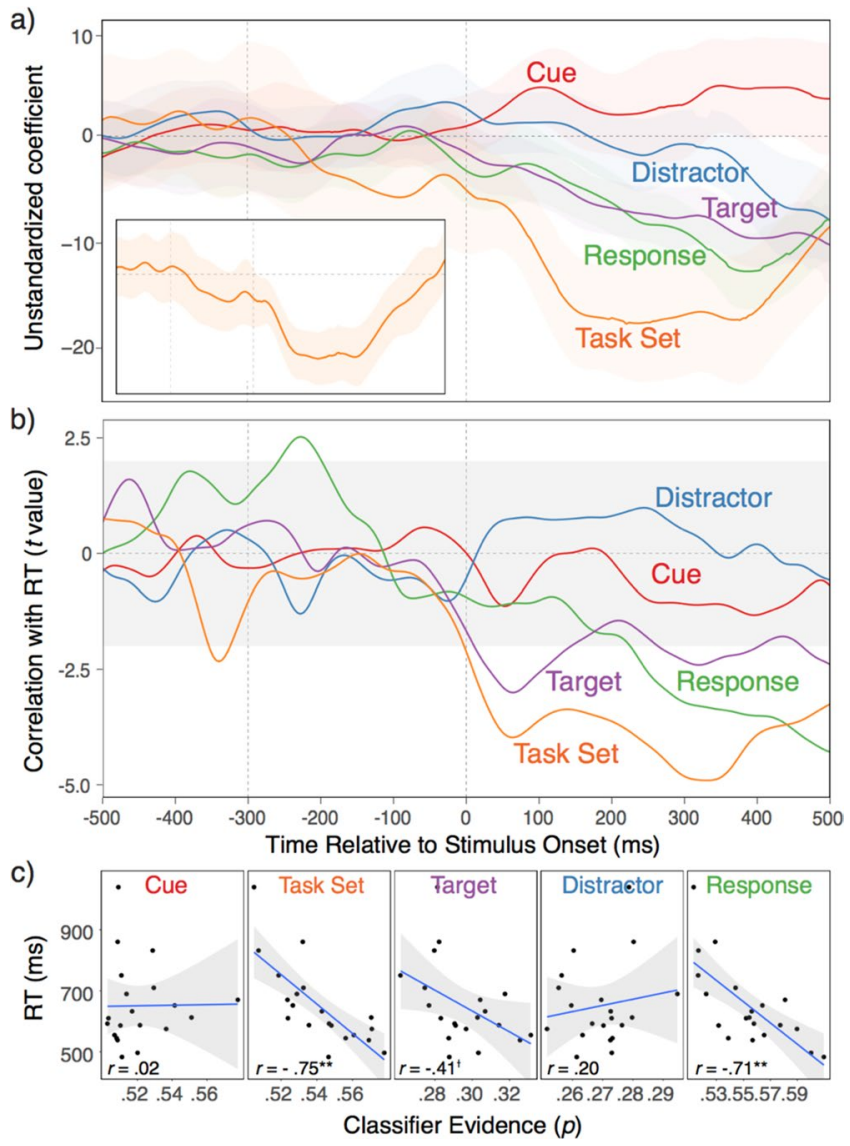

Figure 1. 
(c) (i) Open Access This article is licensed under a Creative Commons Attribution 4.0 International License, which permits use, sharing, adaptation, distribution and reproduction in any medium or format, as long as you give appropriate credit to the original author(s) and the source, provide a link to the Creative Commons license, and indicate if changes were made. The images or other third party material in this article are included in the article's Creative Commons license, unless indicated otherwise in a credit line to the material. If material is not included in the article's Creative Commons license and your intended use is not permitted by statutory regulation or exceeds the permitted use, you will need to obtain permission directly from the copyright holder. To view a copy of this license, visit http://creativecommons.org/licenses/by/4.0/.

(C) The Author(s) 2020 